\title{
STUDIES ON THE ACCELERATING EFFECT OF THIAMINE AND ITS DERIVATIVES ON YEAST FERMENTATION
}

\author{
NORIO SHIMAZONO, SHIGEO HORIE, KUMIKO OKOSHI, \\ TSUNEKI SHINOHARA AND EIJI ORIKABE
}

\author{
Department of Biochemistry, Faculty of Medicine, \\ University of Tokyo, Hongo, Tokyo
}

(Received April 6, 1957)

\begin{abstract}
Many studies on the biological action of thiamine and its derivatives using microorganisms have been reported. Kitahara and Fukui (1) examined the action of thiamine derivatives and antithiamines using Mucor observing the effect of thiamine derivatives on the decrease of pyruvate accumulation. Suzuki et al. (2) studied the action of thiamine allyl disulfide (TAD) on Tetrahymena based on the fact that thiamine reverses the growth inhibition and degeneration of the protozoa by hydroxythiamine. Fukui et al. $(3,4)$ studied using yeast the relationship between the action of hydroxythiamine on the growth and fermentation and the activity of thiamine synthesis. Matsukawa and Suzuoki (5) investigated the correlation of the transfer of thiamine and thiamine alkyl disulfides into yeast cells to energy-rich phosphate systems.

Yeast fermenting at a maximum rate under suitable conditions is known to show a marked promotion of fermentation following addition of a minute quantity of thiamine, as found by Atkin, Schultz, and Frey who deviced an assay method for thiamine by applying this finding. Notwithstanding numerous studies, however, the detailed mechanism of this action of thiamine action remains still unclarified. The authors have investigated this phenomenon more in detail and using an improved method the action of a number of thiamine derivatives, e.g., TAD, thiamine propyl disulfide (TPD), etc., has been studied (6-10).
\end{abstract}

\section{EXPERIMENTAL}

\section{Methods}

Preparation of Yeast_ Pressed baker's yeast supplied by the Oriental Yeast and Co. was mostly used, and that of the Dainippon Sugar-manufacturing Co. (Nitto) was partially used. The former maintained a nearly constant activity throughout the experimental period, showing a relatively pronounced accelerating effect of thiamine on fermentation. If stored in a refrigerator, it retains its activity for at least 10 days. Brewer's yeast having a tendency to aggregate was unsuitable for shaking culture, and no promotion of anaerobic carbon dioxide evolution was found when thiamine was added. 
Determination Method Thiamine was determined largely according to Atkin, Schultz and Frey (11) using the Warburg manometer with $1 / 4$ as much of yeast used in the original method in a vessel of an ordinary size. Yeast was grown with shaking in the stream of nitrogen which flowed out of the vessels through capillary stoppers into a thermostat. The volume of culture fluid was the same as described in the original method so as to be suitable for the determination for a relatively long period, so that the amount was about four times as great as the original method as compared with the amount of yeast.

The nitrogen of the yeast cells was determined by the Kjeldahl method in the modification of Parnas using copper as a catalyst. Cell count and percentage germination were performed microscopically using a blood cell-counting plate and a melangeur for leucocyte counting.

Culture Conditions - Temperature, $30^{\circ}$; $\mathrm{pH} 5.2$; gas phase, $\mathrm{N}_{2}$; time of culture, 2-4 hours; the composition of the basal medium is shown in Table I.

TABLE I

Composition of the Basal Medium

(Expressed in $\mu \mathrm{m}$, if not otherwise noted)

Total fluid volume in a vessel, $2.0 \mathrm{ml} ;$ glucose, $167 ; \mathrm{KH}_{2} \mathrm{PO}_{4}, 2.4 ; \mathrm{CaCl}_{2}, 1.7$; $\mathrm{MgSO}_{4}, 6.1$; niacin, $0.08 ; \mathrm{FeCl}_{3}, 0.01 ; \mathrm{MnSO}_{4}, 0.005$; citrate-phosphate buffer (citric acid 33.3, $\left.\mathrm{K}_{2} \mathrm{HPO}_{4} 79.5\right)$; $\left(\mathrm{NH}_{4}\right)_{2} \mathrm{SO}_{4}, 79.5$; pressed yeast, $1.25 \mathrm{mg}$ (average dry weight $38 \%$, average cell count $\left.15.8 \times 10^{6}\right)$; thiamine or its derivatives, ca. $1-10 \mathrm{~m} \gamma$.

\section{Results}

\section{Examination as an Assay Method for Thiamine}

First, the baker's yeast used by the authors was examined for an assay method and compared with the activity of the Fleischmann yeast used by Atkin et al. For the determination, the reaction mixture was kept at $30^{\circ}$ for one hour, bubbling $800 \mathrm{ml}$ of nitrogen per vessel. After stopping the bubbling and closing the stoppers of manometers and vessels, the zero point was read and the carbon dioxide evolved up to one hour was determined. From the amount of carbon dioxide evolved following the addition of thiamine minus a control value, a calibration curve for thiamine was plotted. Under the authors' conditions, the accelerating effect reached a maximum level with about $10 \mathrm{~m} \gamma$ of thiamine, no further acceleration being found after adding as much as 1,000 $\mathrm{m} \gamma$ of thiamine. According to Atkin et al., a maximum level was reached with ca. $40 \mathrm{mr}$ but his scale was four times greater than the authors'. Since the yeast used by the authors showed roughly the same assay range and the inclination of the curve differed scarcely from that of the Fleischmann yeast, the activity seemed to be about the same. Up to $10 \mathrm{~m} \gamma$ of the thiamine added, carbon dioxide evolved increased proportionally with the thiamine added. Hence, to that extent the microassay for thiamine is possible.

2. Correlation between Nitrogen Metabolism and Acceleration of Fermentation It was already pointed out by Schultz, Atkin, and Frey that ammonium 
salt was necessary as a nitrogen source in the medium. Generally yeast cells are known to show various carbon dioxide evolution curves according to the composition of the medium (12). Also in the authors' experiments, marked differences were observed with or without nitrogen source. In the absence of ammonium sulfate the effect of thiamine was not detectable from the start in the Oriental yeast, whereas in the Nitto yeast the effect disappeared about 30 minutes later. When ammonium sulfate was added afterwards, the accelerating effect of the vitamin added in advance was also observed. In the presence of nitrogen source the fermentation curve rose almost linearly, whereas after the addition of thiamine, the curve gradually increased its slope, manifesting a marked ascending curve 90-120 minutes after the start. The nitrogen content of the yeast cells was found to have increased with time nearly in parallel with the carbon dioxide evolved during anaerobic fermentation, especially marked after the addition of thiamine. An example is shown in Table II.

TABLE II

Relationship between the Amount of $\mathrm{CO}_{2}$ Produced, and the Nitrogen Increased in Yeast Cells (Oriental baker's yeast)

\begin{tabular}{rcccc}
\multicolumn{2}{c}{ To.e produced $(\mu l)$} & \multicolumn{2}{c}{$\mathrm{N}$ in cells $(m g)$} \\
$\min$ & Without thiamine & With thiamine & Without thiamine & With thiamin \\
0 & 0 & 0 & 0.617 & 0.617 \\
120 & 218.5 & 313.5 & 0.722 & 0.807
\end{tabular}

The production of carbon dioxide was determined with yeast cells weighing 1.25 $\mathrm{mg}$ wet weight at the start of the experiment. The amount of nitrogen in cells was determined with the cells weighing $40 \mathrm{mg}$ wet weight at the start.

Furthermore, a vigorous budding of the cells was found in parallel with carbon dioxide production (Table III). Prior to determining both nitrogen amount and percentage germination of the cells, they were sufficiently cooled to stop fermentation.

TABLE III

Rolationship between $\mathrm{CO}_{2}$ Produced and Percentage Cormination

(Oriental baker's yeast)

Percentage germination $=\begin{gathered}\text { Germinating cells } \\ \text { Total cells }\end{gathered} \times 100$

At the beginning of experiment CO. produced Germination

Without thiamine, after 120 minutes

0

per cent

With $250 \mathrm{~m} \boldsymbol{\gamma}$ thiamine, after 120 minutes

321

15

33

472

48 
For determining the increased nitrogen content of the cells, those weighing $1.25 \mathrm{mg}$ wet weight were insufficient. A special $100 \mathrm{ml}$-flask with a side bulb was used and kept shaking with bubbling $\mathrm{N}_{2}$, simultaneously with manometry. Though a little difference was found according to the difference of the kind of yeast, the same tendency was observed in each case. Presumably some differnce appeared according to the difference in the endogenous thiamine, in the activity of thiamine synthesis and in the amount of the materials for protein synthesis present in cells according to the history of cultivation and to the differnce in strain. The total thiamine level of the Oriental yeast is definitely lower than that of brewer's yeast in general, and is lower than most yeasts reported in the literature.

\section{Relationship between Metal Ions and the Acceleration of Fermentation}

For clarifying the accelerating effect of thiamine, a series of experiments were conducted in order to find out inhibiting agents which has no effect on control fermentation and inhibits only the acceleration by thiamine. Many antimetabolites, poisons, chemicals, and antivitamins were examined, but in vain. Potassium cyanide, cysteine, $o$-phenanthroline and $\alpha, \alpha^{\prime}$-dipyridyl were shown to have at least apparent similar action, viz., the effect of thiamine was largely diminished without affecting the fermentation of a control.

The inhibition by cyanide was distinctly observed in the concentration range of $M / 1,000-M / 2,500$ and the effect of thiamine did not restore by adding excessive amount of metal ions, e.g., $\mathrm{Mg}^{++}, \mathrm{Mn}^{++}, \mathrm{Fe}^{++}, \mathrm{Co}^{++}$. A similar inhibition was shown by cysteine (in a final concentration of $M / 1,000$ ) and the effect of thiamine did not restore by the addition of excess heavy metal ions either. $o$-Phenanthroline was effective in the concentration range of $M / 1,000-M / 5,000$ but differing from the former two it restored spontaneously at a low concentra-

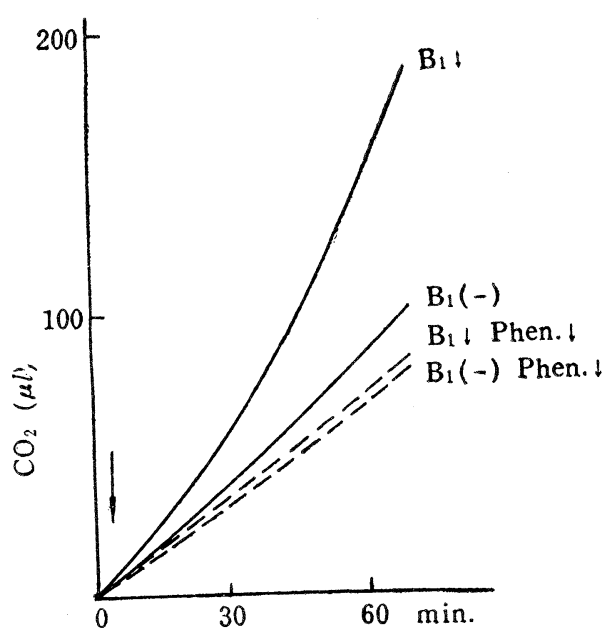

FIG. 1 Influence of o-Phenanthroline on the Effect of Thiamine

$\downarrow 25 \mathrm{mr}$ thiamine added

$\downarrow M / 1000 o$-phenanthroline added tion $(M / 5,000)$ at the end of $30-40 \mathrm{minu-}$ tes and even at a high concentration

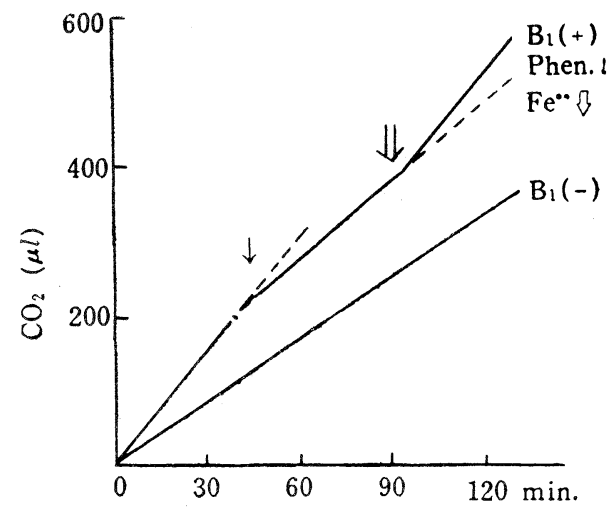

Fig. 2 Effect of $\mathrm{FeSO}_{4}$ on the Inhibition by o-phenanthroline $25 \mathrm{~m} r$ thiamine

$\downarrow \quad M / 1000 o$-phenanthroline added

ת. $M / 500 \mathrm{FeSO}_{4}$ added 
the inhibition disappeared by adding excess heavy metal ions (Figs 1-2).

The activity to reverse inhibition was in the following order: $\mathrm{Fe}^{++} \approx \mathrm{Co}^{++}$ $>\mathrm{Mn}^{++}>\mathrm{Mg}^{++}$. $\mathrm{Fe}^{+++}$has also the similar activity to $\mathrm{Fe}^{++}$, but takes much time, whereby a red color of ferrous $o$-phenanthroline appeared gradually. This shows that the ferric ions added to the medium are gradually reduced to ferrous ions under the condition mentioned above, which suggests that an intensive interchange of metal ions takes place between in- and outside of the cell. Those metal ions themselves show neither inhibition nor acceleration. It can not be a positive evidence that the effect of thiamine is lost by the hindrance of iron metabolism by metal complex-formers, i.e., excess ferrous ions may protect the complex formation of phenanthroline with other metals. $\alpha, \alpha^{\prime}$-Dipyridyl also showed a similar activity but at a far higher concentration $(M / 500)$. The inhibition by this compound was also restored by excessive metal ions. Inhibition by carbon monoxide of the accelerating effect of thiamine was never detected.

4. Accelerating Effect of Thiamine Derivatives on Fermentation

24 kinds of thiamine derivatives, as given in Table IV, were used in the

TABLE IV

Effect of Thiamine Derivatives<smiles>[R]OCCC(S[R2])(S[R])C(C)(C=O)NCC12CN=C([R1])N1C2N</smiles>

\begin{tabular}{|c|c|c|c|c|c|c|}
\hline No. & $\mathrm{R}_{1}$ & $\mathrm{R}_{2}$ & $\mathrm{R}_{3}$ & Name & $\begin{array}{l}\text { Acti- } \\
\text { vity }\end{array}$ & Remark \\
\hline 1 & $\mathrm{CH}_{3}-$ & $-\mathrm{S}-\mathrm{CH}_{2}-\mathrm{CH}: \mathrm{CH}_{2}$ & $-\mathrm{H}$ & TAD & $a$ & \multirow{4}{*}{$\begin{array}{l}\text { As active as, } \\
\text { or slightly } \\
\text { more active } \\
\text { than, } \\
\text { thiamine }\end{array}$} \\
\hline 2 & $\mathrm{CH}_{3}-$ & $-\mathrm{S}-\mathrm{CH}_{2}-\mathrm{CH}_{2}-\mathrm{CH}_{3}$ & $-\mathrm{H}$ & TPD & $a$ & \\
\hline 3 & $\mathrm{CH}_{3}-$ & $-\mathrm{S}-\mathrm{CH}_{2}-\mathrm{CH}_{2}-\mathrm{CH}_{3}$ & $-\mathrm{CO} \cdot \mathrm{CH}_{3}$ & \multirow{2}{*}{$\begin{array}{l}\text { TAD acetylester } \\
\text { TPD propionyl- } \\
\text { ester }\end{array}$} & $a$ & \\
\hline 4 & $\mathrm{CH}_{3}-$ & $-\mathrm{S}-\mathrm{CH}_{2}-\mathrm{CH}_{2}-\mathrm{CH}_{3}$ & $-\mathrm{CO} \cdot \mathrm{C}_{2} \mathrm{H}_{5}$ & & $a$ & \\
\hline 5 & $\mathrm{CH}_{3}-$ & $-\mathrm{CO} \cdot \mathrm{CH}_{3}$ & $-\mathrm{CO} \cdot \mathrm{CH}_{3}$ & DAT & $b$ & \multirow[b]{5}{*}{$\begin{array}{l}\text { Almost the } \\
\text { same as DAT }\end{array}$} \\
\hline 6 & $\mathrm{CH}_{3}-$ & $-\mathrm{CO} \cdot \mathrm{C}_{2} \mathrm{H}_{5}$ & $-\mathrm{CO} \cdot \mathrm{C}_{2} \mathrm{H}_{5}$ & DPT & $b$ & \\
\hline 7 & $\mathrm{CH}_{3}-$ & $-\mathrm{CO} \cdot \mathrm{C}_{6} \mathrm{H}_{5}$ & $-\mathrm{CO} \cdot \mathrm{C}_{6} \mathrm{H}_{5}$ & DBT & $b$ & \\
\hline 8 & $\mathrm{CH}_{3}-$ & $-\mathrm{CO} \cdot \mathrm{C}_{2} \mathrm{H}_{5}$ & $-\mathrm{CO} \cdot \mathrm{C}_{6} \mathrm{H}_{5}$ & $\begin{array}{l}S \text {-propiony-O-ben- } \\
\text { zoyl-thiamine }\end{array}$ & $b$ & \\
\hline 9 & $\mathrm{C}_{2} \mathrm{H}_{5}-$ & $-\mathrm{CO} \cdot \mathrm{CH}_{3}$ & $-\mathrm{CO} \cdot \mathrm{CH}_{3}$ & DAHT & $b$ & \\
\hline 10 & $\mathrm{CH}_{3}-$ & $-\mathrm{CH}_{2} \cdot \mathrm{CH}_{2} \mathrm{OH}$ & $-\mathrm{H}$ & & $c$ & \multirow{4}{*}{$\begin{array}{l}a \\
a\end{array}$} \\
\hline 11 & $\mathrm{CH}_{3}-$ & $-\mathrm{CH}_{2} \cdot \mathrm{CO} \cdot \mathrm{CH}_{3}$ & $-\mathrm{CO} \cdot \mathrm{C}_{6} \mathrm{H}_{5}$ & & $c$ & \\
\hline 12 & $\mathrm{CH}_{3}-$ & $-\mathrm{COOC}_{2} \mathrm{H}_{5}$ & $-\mathrm{CO} \cdot \mathrm{C}_{6} \mathrm{H}_{5}$ & & $c$ & \\
\hline 13 & $\mathrm{CH}_{3}-$ & $-\mathrm{CH}_{2} \cdot \mathrm{CH}_{2} \mathrm{OH}$ & $-\mathrm{CO} \cdot \mathrm{C}_{6} \mathrm{H}_{5}$ & & $c$ & \\
\hline 14 & $\mathrm{CH}_{3}-$ & $-\mathrm{CH}_{2} \cdot \mathrm{CO} \backslash \mathrm{NO}_{2}$ & $-\mathrm{H}$ & & $d$ & \\
\hline 15 & $\mathrm{CH}_{3}-$ & $-\mathrm{CH}_{2} \cdot \mathrm{COOH}$ & $-\mathrm{CO} \cdot \mathrm{C}_{6} \mathrm{H}_{5}$ & & $d$ & \\
\hline
\end{tabular}


<smiles></smiles>

\begin{tabular}{|c|c|c|c|c|c|c|}
\hline No. & $\mathrm{R}_{1}$ & $\mathrm{R}_{2}$ & $\mathrm{R}_{3}$ & Name & $\begin{array}{l}\text { Acti- } \\
\text { vity }\end{array}$ & Remark \\
\hline 16 & $\mathrm{CH}_{3}-$ & $-\mathrm{OH}$ & & Hydroxy-thiothiamine & $d$ & No antithiamine \\
\hline 17 & $\mathrm{C}_{4} \mathrm{H}_{9}$ & $-\mathrm{NH}_{2}$ & & Butyl-thiothiamine & $d$ & $\begin{array}{l}\text { activity with } \\
\text { equimoles to }\end{array}$ \\
\hline 18 & $\mathrm{CH}_{3}-$ & $-\mathrm{NH}_{2}$ & & Thiothiamine & $d$ & thiamine \\
\hline
\end{tabular}

\begin{tabular}{|c|c|c|c|c|c|c|}
\hline 19 & $\mathrm{CH}_{3}-$ & $-\mathrm{OH}$ & $-\mathrm{H}$ & Hydroxy thiamine & $d$ & $\begin{array}{l}\text { No antithiamine } \\
\text { activity with } 1,10 \\
\text { and } 100 \text { moles to } \\
\text { thiamine }\end{array}$ \\
\hline 20 & $\mathrm{C}_{4} \mathrm{H}_{9}-$ & $-\mathrm{NH}_{2}$ & $-\mathrm{H}$ & Butyl-thiamine & $d$ & $\begin{array}{l}\text { No antithiamine } \\
\text { activity with } \\
\text { equimoles to } \\
\text { thiamine }\end{array}$ \\
\hline 21 & $\mathrm{CH}_{3}-$ & $-\mathrm{NH}_{2}$ & $-\mathrm{CO} \cdot \mathrm{CH}_{3}$ & $O$-Acetyl-thiamine & $d$ & \\
\hline 22 & $\mathrm{CH}_{3}-$ & $-\mathrm{NH}_{2}$ & $-\mathrm{CO} \cdot \mathrm{C}_{6} \mathrm{H}_{5}$ & $O$-Benzoyl-thiamine & $d$ & \\
\hline
\end{tabular}

No thiamine action and no antithiamine action

experiment including thiamine alkyl disulfides, (e.g., TAD, TPD), O,S-diacyl derivatives, (e.g. diacetyl thiamine, DAT, dibenzoyl thiamine, DBT), and antithiamines.

As stated above, carbon dioxide production reached a maximum level with $10 \mathrm{~m} \gamma$ thiamine under the experimental conditions, and this fact must be taken into consideration for determining the activity of each derivative. Thiamine derivatives equimolar to $10 \mathrm{~m} \gamma$ of thiamine was tentatively called $10 \mathrm{~m} \gamma$ equivalent $(10 \mathrm{~m} \gamma \mathrm{E})$, and the activity of each derivative was determined using this equivalent as a standard. Derivatives appoximately as active as thiamine were examined at varying concentrations. Further, for comparing the activity, the course of the appearance of the activity with time was also noticed.

Fig. 3 represents the results classified in four groups: (a) Almost as active as thiamine; (b) The activity appeared more slowly than thiamine, but it became almost as active as thiamine 2.5-4.0 hours after starting the culture; $(c)$ The 


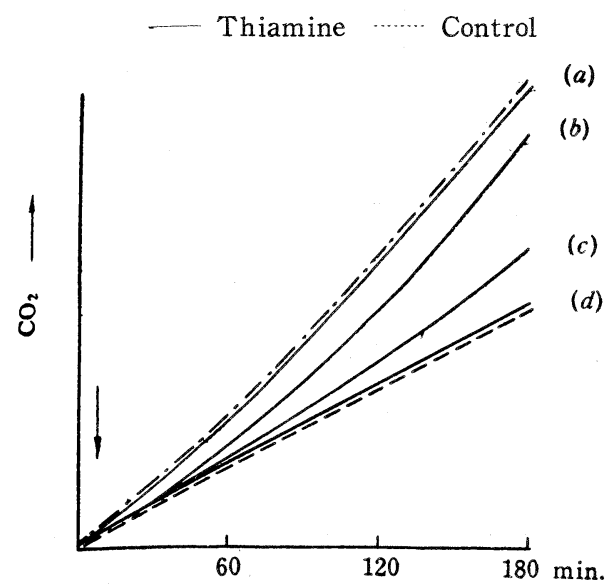

FIG. 3 Classification of the Activities of Thiamine Derivatives

activity appeared later and less than thiamine even after a long culture; (d) Scarcely any activity was detected. The activity of each derivative is listed in Table IV. Compounds Nos. $1-4$ in the Table belong to Type $a$ in Fig. 3 , being as active as, or somewhat more active than, thiamine. After the addition of TAD or TPD at varying concentrations, $\mathrm{CO}_{2}$ evolution approached to the maximum level earlier than after adding thiamine (Fig. 4). Isobe (13) observed the penetration of TPD into yeast cells in the form of thiamine. If her results are converted to those under the authors' conditions, TPD enters the cells more than thiamine at the level lower than $100 \mathrm{~m} \gamma E$ but enters less than thiamine at the level of $1000 \mathrm{~m} \gamma E$. Since TAD or TPD enters the cells more easily at lower levels, it is assumed to reach the final $\mathrm{CO}_{2}$ level earlier than thiamine.

Of the compounds Nos. 1-4, TAD and TPD were equally active or somewhat more active than thiamine, and TPD acetylester and TPD propionylester were more active than $O$-acetyl thiamine. These findings suggest that the alkyl disulfide derivatives of thiamine with open thiazole ring is somewhat more active than that with a closed ring.

Compounds Nos 5-9 belong to Type $b$ in Fig. 3, whose effect appears later than thiamine, but their activities reach the value of thiamine after a long period. The effect appeared earlier in the order: DAT $>$ DPT $>S$-propionyl$O$-benzoyl-thiamine $>$ DBT. Compounds having an acyl group to $\mathrm{S}$ alone and no substitution at $\mathrm{O}$ were not available owing to the difficulty of synthesis. Compounds Nos. 10-13 showed a slight activity, but compounds Nos. 14 and 15 lacked any activity. These are to be included in $S$-alkyl forms, which has been reported to be inactive to animals. 
Thiothiamine and its derivatives, as well as butylthiamine and hydroxy. thiamine, failed to show any thiamine effect on yeast cells. The antivitamin action of these compounds will be described in the following part.

The compounds Nos. 21 and 22 contain a thiazole ring and can not serve as a direct control of DAT and DBT, but considering that the alcoholic OH of these two compounds are esterified with an acyl group and that they are less active than thiamine, it is assumed that the acyl group at $O$-position may chiefly limit the effect of DAT and DBT. Isobe ${ }^{1}$ observed the transfer of various derivatives into erythrocytes and found $O$-acyl group to be inhibitory and $S$ acyl group to be accelerating.

\section{Action of Antivitamins}

Fukui et al. (3-4) have studied the action of antitvitamins on yeast fermentation. The auhors examined the behavior of antivitamins under the conditions described above. It was considered to serve as a help for knowing the limit or restriction to presume the effect of thiamine on animal cells from the effect on yeast cells.

Hydroxythiamine Hydroxythiamine does not eliminate the thiamine effect, as shown in Table IV, at levels 1, 10, and 100 times that of thiamine. At higher concentrations at a final concentration of more than $M / 10,000$, it gives a definite effect, lowering the evolution of carbon dioxide with the lapse of time. However, in the presence of $1 / 1,500-1 / 30,000$ of thiamine, the action of hydroxythiamine was entirely counteracted.

Butylthiamine - Thiamine action was not eliminated by the addition of an equal amount of butylthiamine as shown in Fig. 4. Butylthiamine, at a final concentration of $M / 1,000$, not only lacks an antithiamine action, but promotes yeast fermentation to the same limit as that reached by thiamine. From the above finding it is evident that butylthiamine does not act as an antivitamin to yeast cells but the significance of the fact that an extremely large amount of butylthiamine has a thiamine action remains unclarified. In this case, thiamine, ethylthiamine, etc. were not detected in the sample by faper chromatography, but an impurity having a $R_{\mathrm{F}} 0.17$ was detected by development with $n$-butanol-acetic acid-water ( $4: 1: 1)$ ( $R_{\mathrm{F}}$ of thiamine, 0.43 ; butylthiamine, 0.6$)$. Three possibilities are considered, viz., butylthiamine was decomposed by yeast cells similarly to hydroxythiamine as reported by Fukui et al., or the decomposition product was utilized for thiamine synthesis, or by the impurity mentioned above effected.

Heteropyrithiamine - The structure of heteropyrithiamine (13) is shown in Table IV. Neither antithiamine action nor accerelating action was observed even at a final concentration of $M / 1,000$ (900 $\gamma$ per flask).

Of the three antithiamines tested hydroxythiamine alone was found to show an antithiamine action to yeast fermentation.

\section{DISCUSSION}

On the Accelerating Mechanism by Thiamine — From the form of the

\footnotetext{
1 Not yet published.
} 
fermentation curve of an increased carbon dioxide production followed by thiamine addition, the authors have set up following working hypothesis: First, thiamine acts upon an energy-metabolic system producing energy-rich comfounds which makes more substrates available for synthesis of both nucleic acids and proteins as well as enzyme systems, thus leading to utilization of more energy sources and production of more energy, i.e., the accelerating effect of thiamine is an over-all expression of a complicated mechanism in which all the multienzyme systems in yeast cells participate, bring about continuous growth and reproduction. For proving the first stage of this hypothesis the action of thiamine on energy-metabolic system should be demonstrated, but such a biochemical method for treating the change in whole cells is not yet settled. While this study was under way, the paper of Trevelyan and Harrison (14) dealing with the determination of intracellular pyruvate appeared. They determined the intracellular pyruvate by substracting the extracellular pyruvate from total pyruvate. Taking this value as a substrate concentration, and the rate of $\mathrm{CO}_{2}$ production as a reaction rate, they obtained values in good agreement with the formula of Michelis and Menten. Furthermore, the intracellular pyruvate was shown to fall very rapidly (within 3 minutes) and the increase in extracellular pyruvate was stopped by thiamine addition. They concluded from kinetic studies that it was due to the promotion of cocarboxylase activity rather than an increased affinity of carboxylase for its substrate.

This dramatic action of thiamine in a short time is, according to their view, due to the formation of a holoenzyme by combining the phosphorylated thiamine with the apoenzyme or its precursor. As regards this point, the authors do not exclude the possibility that in the pressence of thiamine the amount of cocarboxylase in a dynamic equilibrium in cells rises or the stabitity of cocarboxylase increases, viz., thiamine itself influences the activity of a reaction system directly or indirectly. At any rate, the synthesis of protein in such a short time is hardly comprehensive. The view of Trevelyan that at least in the early stages, actual protein synthesis is not involved, i.e., that the process is one of supplying coenzyme to pre-existing apocarboxylase is to be affirmed.

On the other hand, Went (15) assumes that the consumption of energy-rich phosphate bonds caused by the stimulation of protein metabolism following thiamine addition leads indirectly to the increase in carbon dioxide production. However, it must be considered that the yeast can also synthesize lipids, phosphoric acid ester of sugars, glycogen and polyphosphoric acid.

The definite increase in carbon dioxide production in maximally fermenting yeast following thiamine addition appears at least after 15-20 minutes, occurring very slowly. It takes place only in the presence of nitrogen sources and the increase in carbon dioxide output roughly parallels both the nitrogen amount in cells and the increase in percentage germination, so that it may reasonably be assumed that at least in later stages the effect of thiamine is coupled with nitrogen metabolism.

On the Effect of Metal Ions - It is well known that carboxylase activity is promoted by a trace of $\mathrm{Mn}^{++}$or $\mathrm{Mg}^{++}(16,17)$, but the experiments suggesting the relationship between thiamine metabolism and metal metabolism in 
microorganisms or in animal body can not be interpreted by this fact alone.

Thus Perla and Sandberg (18) found a relationship between thiamine metabolism and manganese metabolism, and manganese was assumed to act as an oxidative catalyst when thiamine is utilized in tissues. Perla (19) observed the accumulation of mangenese in thiamine-depleted rats and the intoxication due to extremely excessive thiamine could be prevented by a small amount of manganese. Weil-Malherbe (27) studied the synthesis of cocarboxylase by phosphorylating thiamine using yeast and found the necessity of $\mathrm{Mn}^{++}$or $\mathrm{Mg}^{++}$. The same results were also obtained in animal tissues $(28,29)$. Correlation with iron and copper metabolism is not clear. Though a detailed presumption is not possible from the authors' simple inhibition experiments, it is of some interest that the effect of thiamine hardly appears in the experiment using cells in the presence of substances which are known to form a complex with metal ions.

On the Permeability of Cells_- The behavor of penetration into cells is known to be distinctly different between thiamine and TPD, the latter entering the cells much easier than the former. It is a property of TPD characteristic and beneficial. In the test for activity using fermenting cells, the permeability of the derivatives is always a prerequisite.

On the Effect of Each Derivative TAD is known to be as effective as thiamine in the test for growth of rats or Uroloncha domestica $(20,21)$, as well as in the curative test of rats and readily absorbed from the intestine (22). Furthermore, it is transferred into erythrocyte far easier than thiamine, occurring in the cells as thiamine (23). TPD has also the similar property. In the authors' experiments with yeast, TPD was found to be as active as, or a little more active than, thiamine and its accelerating effect reached the maximum level at concentrations slightly lower than thiamine. Aramaki et al. (24) performed animal experiments with DAT and DBT. Suzuoki (26) observed that both DAT and DBT were inferior to thiamine alkyl disulfides in the transfer into erythrocytes and in the durability of the level in blood, but the excretion of DBT was markedly retarded after an intramuscular injection because of its hard solubility in water. Both of these were found to be converted into thiamine in the body. It is a fact of some interest that the appearence of DBT action was definitely retarded in the authors' experiments. It is possibly dependent on the permeability of yeast and on the activity of deacylase on benzoyl group.

In general, $S$-alkyl forms (containing -S-C-linkage) have no thiamine action on animals and little, if any, action on yeast. Thiothiamines have no activity in yeast, whereas they are reported to have a weak activity in animals. The action of antivitamins in yeast were found to differ markedly from that in animals as mentioned above.

On the Limit of the Biological Test - Thiamine action in yeast is similar in many respects with that in animals, and the specific activity of thiamine derivatives in yeast is similar with that in animals. However, it must be taken into consideration that in this test anaerobic fermentation of unicellular microorganisms is observed, which are capable of synthesizing thiamine more or less and also of synthesizing thiamine from the constituent of the vitamin, es- 
pecially from the pyrimidine moiety. Further, yeast accumulates thiamine, much more than is necessary, using energy (26). Therefore, the compounds which are primarily inactive as thiamine can be partially converted by yeast into an active derivative or degraded to form the pyrimidine moiety, which is then utilized. Furthermore, thiamine pyrophosphate is a coenzyme active for oxidative decarboxylation of pyruvate in animal tissues, whereas in yeast it is active for anaerobic decarboxylation of pyruvate in fermentation. The action mechanism can therefore not be quite the same.

Considernig these restrictions and knowing the fundamental universality of cell metabolism, the accelerating effect of thiamine on anaerobic fermentation in yeast is said to be one of the powerful, simple biological test and may serve as a useful screening test of a number of thiamine derivatives.

\section{SUMMARY}

1. Using Atkin-Schultz-Frey's microbiological assay for thiamine based on the accelerating effect of thiamine on yeast fermentation, the effect of thiamine and of 24 derivatives on anaerobic decarboxylation was examined.

2. This method can be applied as a biological test of thiamine derivatives, if it is taken into consideration that the action on yeast is not always in agreement with that on animals.

3. Following thiamine derivatives were examined; (a) S, S-alkyl derivatives show the accelerating effect as much as, or a little more than, thiamine. (b) Of $O, S$-diacyl thiamines, $O, S$-diacetyl thiamine is as active as thiamine and the effects of other compounds appeared in the following decreasing order.

$O, S$-Diacetyl $>$ dipropionyl $>S$-propionyl-O-benzoyl $>$ dibenzoyl. Once the effects have appeared, they were all as active as thiamine. (c) O-Acyl derivatives were somewhat inferior to thiamine. (d) $S$-Alkyl derivatives have generally little activity, if any. (e) Thiothiamines have no activity. ( $f$ ) As antivitamins, hydroxythiamine, butylthiamine and heteropyrithiamine were examined, of which hydroxythiamine alone showed a slight antithiamine activity.

4. As for the mechanism of accelerating effect, the relation to nirogen metabolism is important, and the effect of nitrogen sources, increase in nitrogen in cells and promotion of budding were observed. Further, participation of metal ions and the permeability of cell membrane were observed.

\section{ACKNOWLEDGEMENTS}

This work was supported by a grant of the Vitamin B Research Committee. The authors are deeply indebted to Dr. Taizo Matsukawa, the Takeda Reseach Laboratory, for the kind gifts of various thiamine derivatives, and to Dr. Seiji Kasuga, Kanto Communication Hospital, for his kind advice at the beginning of this work.

\section{REFERENCE}

1. Kitahara, K., and Fukui, S., Bioassay (Japanese) 2, 10 (1955).

2. Suzuki, N., Kishida, T., Yamaguchi, M., Nakayama, F., and Ito, Y., Vitamins 7, 910 (1954). 
3. Fukui, S., Shigehara, K., and Kishibe, T., Fermentation Technology (Japanese) 28, 465 (1950).

4. Fukui, S., and Kishibe, T., ibid. 29, 6 (1951).

5. Matsukawa, T., and Suzuoki, N., Vitamins 7, 75 (1954) ; J. Biochem. 42, 27 (1955).

6. Shimazono, N., Horie, S., and Okoshi, K., Vitamins 6, 967 (1953).

7. Shimazono, N., Horie, S., and Shinohara, T., ibid. 7, 302 (1954).

8. Shimazono, N., and Horie, S., ibid. 7, 474 (1954).

9. Horie, S., ibid. 7, 795 (1954).

10. Shimazono, N., Horie, S., and Orikabe, E., ibid. 7, 795 (1954).

11. Atkin, L., Schultz, A. ", and Frey, C. N., J. Biol. Chem. 129, 471 (1939).

12. Nilson, R., and Frithoif, A., Z. physiol. Chem. 239, 179 (1936); Biochem. Z. 286, 254, 373 (1936); 304, 385 (1940).

13. Fujita, A., Nose, Y., Ueda, K., and Hasegawa, E., J. Biol. Chem. 196, 297 (1952).

14. Trevelyan, W. E., and Harrison, J. S., Biochem. J. 57, 556, 561 (1954).

15. Went, L. N., Chem. Weekbl. 45, 341 (1949).

16. Lohmann, K., and Schuster, P., Biochem. Z. 294, 183 (1937).

17. Ochoa, S., and Peters, R. A., Biochem. J. 32, 1501 (1938).

18. Perla, D., and Sandberg, M., Proc. Soc. Exptl. Biol. Med. 41, 522 (1939) ; 42, 368 (1939).

19. Perla, D., Science 89, 10 (1939).

20. Fujiwara, M., Watanabe, H., and Matsui, K., J. Biochem. 41, 29 (1954) ; Fujiwara, M., Nanjo, H., Arai, T., and Suzuoki, Z., 41, 273 (1954).

21. Suzuoki, N., Kurihara, M., and Suzuoki, Z., Vitamins 6, 432 (1953).

22. Watanabe, H., ibid. 6, 129 (1953).

23. Matsukawa, T., and Suzuoki, N., ibid. 6, 626 (1953).

24. Aramaki, Y., Watanabe, Y., and Suzuoki, N., ibid. 7, 118 (1954).

25. Suzuoki, N., ibid. 7, 794 (1954).

26. Takata, R., and Ichikawa, K., ibid. 7, 535 (1954).

27. Weil-Malherbe, H., Biochem. J. 33, 1997 (1939).

28. Steyn-Parvé, E. P., Biochem. Biophys. Acta 8, 310 (1952).

29. Mano, Y., Proc. 9th Symposium on Enzyme Chemistry (Japanese) 128 (1956). 